\title{
The Thaler of Maria Theresa from 1780: Der Levantetaler
}

The thaler of the queen and empress Maria Theresa, minted in her last regnal year of 1780 , is one of the most famous silver coins in the world. Thaler is a type of large silver coin (around $40 \mathrm{~mm}$ in diameter, weighing around $30 \mathrm{~g}$ ) that was used throughout Europe for almost 400 years. Because of its high quality and beautiful craftsmanship, the thaler of Maria Theresa was in use as a trade coin from 1780 until as recently as the 1960 s.

Keywords: silver coin, thaler, Maria Theresa's thaler from 1780, Levant, Arabian Peninsula, Ethiopia

The thaler of Maria Theresa first minted during the last regnal year of the great queen and empress Maria Theresa (1740-80), is one of the most famous silver coins in the world. During almost 200 years, more than 400 million of these coins were struck. They are still minted by the Austrian Mint, not as circulating and trade coins of course, but rather as souvenirs and gifts.

But first and foremost, what is a thaler? Simply put, it is a large silver coin (around $40 \mathrm{~mm}$ in diameter, weighing around $30 \mathrm{~g}$ ) used throughout Europe for almost 400 years. Etymologically speaking, thaler means a person or a thing from a valley or dale, Thal being the German word for valley or dale.

After the Crusades (late $13^{\text {th }}$ century) there was a significant improvement of trade with the East. Europe coveted porcelain, silk, and spices; yet Europe had little to give in return. During the period of the Great Geographical Discoveries (second part of the $15^{\text {th }}$ and throughout the $16^{\text {th }}$ century), with new trading routes

Kristian Gotić, Croatian History Museum, Matoševa 9, 10000 Zagreb, Croatia, E-mail: k.gotic@ hismus.hr 
being created, the trade between East and West increased immensely. The imbalance in trade was huge and to cover its trade deficit ${ }^{1}$ Europe increased its silver production, since silver was the only thing it could offer to acquire the much desired Eastern goods. This led to creating larger silver coins that could be used to facilitate this trade; the tradesmen's Republic of Venice issued the lira $\operatorname{tron}^{2}( \pm 7 \mathrm{~g})$ in 1472, while the Duchy of Milan started issuing its teston ${ }^{3}( \pm 10 \mathrm{~g})$. These coins had the same value as the unit of account, a theoretical denomination to which merchants referred in the transactions they entered in their books. The success of these coins enabled the minting of larger and heavier coins. Finally, in 1486, and using the silver deposits extracted at Schwaz in Tyrol (present day Republic of Austria), Archduke Sigismund ${ }^{4}$ began minting a large number of Guldengros$c h e n^{5}$ at Hall. And thus the first truly thaler-type coin came into existence. These Guldengroschen, often abbreviated as guldiner, ${ }^{6}$ were a success. By the 1520 s, guldiners were surfacing in various places throughout Central Europe. In 1516, a rich silver vein was discovered on the southern slopes of the Ore Mountains Range (Erzgebirge), in the fiefdom of the Counts of Schlick. Soon the minting of guldiners began in the basement of the Counts' castle Freidenstein in the valley of St Joachim's (Sankt Joachimsthal - present day Jáchymov in the Czech Republic).

\footnotetext{
1 This was nothing new in trade relations between East and West. Pliny the Elder (23-79 AD) laments the constant draining of money from the Roman Empire in his Natural History: minimaque computatione miliens centena milia sestertium annis omnibus India et Seres et paeninsula illa imperio nostro adimunt: tanti nobis deliciae et feminae constant. quota enim portio ex illis ad deos, quaeso, iam vel ad inferos pertinet? Pliny, Natural History IV / Libri XII - XVI, trans. Harris Rackham (Cambridge, MA: Harvard University Press, 1960), 62.

2 The term lira is derived from the Latin word libra meaning pound. Doge Nicolò Tron (1471-73) introduced the lira tron with his bust on the obverse and the lion of St Mark on the reverse. It was divided into 20 soldi of twelve denari. Albert R. Frey, A Dictionary of Numismatic Names their Official and Popular Designations (New York: The American Numismatic Society, 1917), 136.
}

3 From the Italian testa meaning head, therefore, any coin with a head upon it. The name first applied to the silver coins of Louis XII of France. Testone is the Italian form of the word teston. Fine specimens of these coins were struck in Milan during the reign of Sforza's (1450-1500). Frey, A Dictionary of Numismatic Names, 238.

4 Sigismund of Tyrol (b. October 26, 1427, Innsbruck; d. March 4, 1496, Innsbruck), Duke of Austria (Archduke from 1477), sovereign in Tyrol and Vorder-Österreich (the Habsburg lands in Southern Germany). Peter Schmid, "Sigmund (Siegmund, Sigismund[us] 'der Münzreiche”, in: Neue Deutsche Biographie (online), vol. 24 (Munich: Historische Kommission bei der Bayerischen Akademie der Wissenschaften, 2010).

5 The golden groat being of silver but of equal value as a gold gulden [weighing around $1 \mathrm{oz}(31.1 \mathrm{~g})$ of silver]. Frey, A Dictionary of Numismatic Names, 102.

${ }^{6}$ It was important for the authorities that issued these coins to indicate the link (by name) of the coins to gulden (golden coin). They wanted to emphasise that these coins had the same value as those of gold by reason of their weight $( \pm 30 \mathrm{~g}$ ) and their fineness (more than 900 pure content). Christiane Logie, “The Thaler. European Coinage of Modern Times", in: One Money for Europe, catalogue of the exhibition held at the $11^{\text {th }}$ International Congress of Numismatics, September 8-13, 1991, ed. Monique Sibille and Lieve Viaene-Awouters (Brussels: Belgian Municipal Credit Institution, 1991), 121. 
These guldiners bore the image of St Joachim, father of the Virgin Mary, together with the coat of arms of the Counts of Schlick on the obverse and the Bohemian lion on the reverse. ${ }^{7}$ They were named Joachimstaler after the place where they were minted, and weighed $\pm 29 \mathrm{~g}$. Similar coins began to be minted in silver-rich valleys, each named after the particular thal or valley from which they came. There were soon so many of them that these silver coins began to be known more widely as thalers. The Imperial Diet (Reichstag) of 1566 introduced the Reichstaler (Imperial thaler) as the official coin of the Holy Roman Empire. The coin was set to contain $1 / 9^{\text {th }}$ of the Cologne mark of silver ( $\pm 26 \mathrm{~g}$ of pure silver). After the chaos of the Thirty Years' War (1618-1648), a new standard had to be introduced. In 1750 , Prussia adopted a thaler containing $1 / 14^{\text {th }}$ of the Cologne mark of silver ( $\pm 16 \mathrm{~g}$ of pure silver). This standard was referred to as the Graumannscher Fuß. ${ }^{8}$ In the Habsburg domains, a new standard was also introduced in 1750, replacing the Reichstaler. It was a thaler minted from $1 / 10^{\text {th }}$ of the Cologne mark of silver, containing around $24 \mathrm{~g}$ of pure silver. After the Coin Convention of 1753, this type of thaler was known as Conventionstaler. It was used in Southern German states and in Saxony. During the early $19^{\text {th }}$ century, the Conventionstaler was superseded by a thaler containing $1 / 14^{\text {th }}$ of the Cologne mark of pure silver, based on the Prussian thaler, which heralded a greater Prussian influence within the German Confederation. After the Viennese Coin Convention of 1857, a new thaler was introduced as standard for the member states of the German Customs Union (Zollverein). The Union thaler, or Vereinstaler, contained $16.666 \mathrm{~g}$ of pure silver $\left(1 / 30^{\text {th }}\right.$ of the metric pound). The Austro-Hungarian Empire stopped issuing the Vereinstaler in 1867, after the Austro-Prussian War. In Germany, it was replaced with the Goldmark after the German Unification of 1871. The Vereinstaler coins continued to circulate as 3 mark coins until 1908, when they were replaced with smaller 3 mark coins. The name thaler for 3 marks persisted until the 1930s.

Due to its success, the thaler, or rather a thaler-type coin, was introduced throughout Europe and for the European trade worldwide. In the Netherlands, thalers were known as daalder. The Leeuwendaalder (lion thaler - because of the lion on the reverse of the coin) was issued from 1576 , had a weight of $\pm 28 \mathrm{~g}$ and only 750 pure content. These coins were basically trade coins, mostly used to trade with the Levant, and were struck up to the $18^{\text {th }}$ century. At the end of the $16^{\text {th }}$ century, the Rijksdaalder appeared - the Dutch equivalent of the Reichstaler. In the Scandi-

\footnotetext{
Inscription on the obverse of the Joachimstaler: S(anctvs) I(oachim) AR(ma) : DOM(inorvm) : SLI(ckorvm) : STE(phani) : E(t) : 7 : FRA(trvm) : COM(itum) : D(e) : BA(ssano). On the reverse: LVDOVICVS · PRIM(vs) D(ei): GRACIA REX BO(hemiae). The Joachimstaler was minted during the reign of Louis I (1516-26) of Bohemia, Louis II of Hungary and Croatia.

8 Named after Johann Philipp Graumann (b. ca. 1706, Braunschweig? - d. 1762, Berlin) Master of the Mint during the reign of Frederick II of Prussia. Arthur Suhle, “Graumann, Johann Philipp", in: Neue Deutsche Biographie (online), vol. 7 (Munich: Historische Kommission bei der Bayerischen Akademie der Wissenschaften, 1966).
} 
navian countries, the Rigsdaler was the Danish equivalent of the Reichstaler, and in Sweden King Gustav I Vasa (1523-60) introduced the Riksdaler and divided it into 12 marks. Because of the economic pressure of foreign competition, in 1551 the King of England began issuing silver coins with the same value as the gold ones; the gold crown of \pm 3.10 g was equal to the silver crown of $30 \mathrm{~g}$. In France, the écu blanc ${ }^{9}$ appeared under Louis XIII in 1641. Russia was also influenced by the thaler and from the $16^{\text {th }}$ century a large number of foreign thalers were present in that realm. Provided with countermarks, these coins circulated under the name of yefimok / ефимок, the Russian transcription of the name Joachim. In the $17^{\text {th }}$ century, efforts were made to equate the thaler with the rouble. These efforts failed because the thaler was too light; it should have weighed $45 \mathrm{~g}$ to match the rouble. In the $18^{\text {th }}$ century, however, Peter the Great (1696-1725) reorganized the Russian monetary system and introduced a rouble of $\pm 27 \mathrm{~g}$ based on the thaler. In Spain, Charles V (Holy Roman Emperor 1519-56, Carlos I of Spain from 1516 until 1556) expanded the issue of Real de a Ocho, a coin that had a nominal value of 8 reales and a weight of about $28 \mathrm{~g}$. This coin was also known as Peso de Ocho (the piece of eight) or Spanish Dollar. Because of the Pillars of Hercules (the Strait of Gibraltar - doorway to the Spanish overseas territories) on the reverse it was called Piastre or Piastra (pier thaler) and Colonnado (column thaler). These coins were minted in Sevilla, Mexico, and Potosi (present-day Bolivia). The enormous quantities of silver from South American mines allowed for the minting of huge quantities -more than 10 billion up to 1854 . Because of their high quality, these coins dominated the world trade in the $17^{\text {th }}$ and $18^{\text {th }}$ centuries, and in fact became the first world currency. It is no surprise then that at the end of the $18^{\text {th }}$ century the newly independent British colonies tailored their currency according to the Colonnado, giving the newly formed legal tender the anglicized name for thaler - the dollar.

During the long reign of the queen and empress Maria Theresa, different types of thaler were struck. From her first thaler minted in 1741 according to the Reichstaler standard, and the Conventionstalers minted in the 1750s, to thalers struck after her husband's death in 1765, none acquired the fame of the one minted in 1780, in her last regnal year. The Maria Theresa Thaler of 1780 is a Conventionstaler containing $1 / 10^{\text {th }}$ of a Cologne mark of silver. It is between 39.5 and 41 $\mathrm{mm}$ in diameter, $2.5 \mathrm{~mm}$ thick and weighs $28.0668 \mathrm{~g}$ containing $23.3890 \mathrm{~g}$ of fine silver. On the obverse of the coin, there is a bust of Maria Theresa wearing a discrete veil with a pearl diadem on her head and a brooch with pearls on her right shoulder. Beneath the bust, there are the initials of the mint masters Tobias

\footnotetext{
The silver écu or écu blanc had a value of 60 sols. Originally, the écu was a gold coin named after the shield that appeared on it (scudo in Italian, escudo in Spanish), minted for the first time during the reign of Louis XI of France in 1266. Frey, A Dictionary of Numismatic Names, 75-76.
} 
Johann Schöbl and Josef Faby (S.F.). ${ }^{10}$ Around the edge of the coin, there is an inscription in Latin: M. THERESIA D.G.R.IMP.HU.BO.REG. ${ }^{11}$ On the reverse, there is a crowned imperial double-headed eagle, with a double-crowned coat of arms on his chest. The coat of arms is divided into four equal parts containing the coats of arms of Hungary, Bohemia, Burgundy, and Burgau, with the coat of arms of Austria in the centre. Around the edge, the inscription from the obverse continues in Latin, ${ }^{12}$ with the mint year (1780) and a saltire $-\mathrm{X}$, meaning the coin is a Conventionstaler containing $1 / 10^{\text {th }}$ of a Cologne mark of silver. Around the rim of the coin, one reads the motto of Maria Theresa's reign: IUSTITIA ET CLEMENTIA (Justice and Clemency). The engraving was done by Johann Martin Krafft, engraver of the Viennese Central Mint.

Thalers were present in trade with the Orient from the second half of the $16^{\text {th }}$ century - especially the Dutch lion thalers (Leeuwendaalder). Due to the trade deficit, there were always a large number of European coins present in the East. By the end of the $18^{\text {th }}$ century, the Leeuwendaalder was replaced with the Spanish dollar and Maria Theresa's thaler as the favoured trade coins in the Levant. Various types of thaler struck under Maria Theresa were preferred by the French merchants of Marseille, which was the most important port for trade with the Levant. The profit they gained from trading in thalers ranged between 10 and 15 kreuzers ${ }^{13}$ per thaler. From 1764, Maria Theresa's thalers were minted at Günzburg near the town of Augsburg - one of the centres of German silver trade with close ties to Marseille - where many of these coins made their way into the pockets of French merchants who had dealings in the region. The spread of Maria Theresa's thaler was also encouraged by the fact that from 1785 French merchants needed to use foreign currency to make their purchases because of the restrictions levied on the export of French silver. Coffee trade also brought large numbers of Maria Theresa's thalers to southern Arabia and the Horn of Africa. From there, Arab merchants and slavers spread the coin down the western coast of Africa to Madagascar, to the lands of Maghreb, Central Africa, and southwards along the eastern African coast to the Portuguese colony of Moçambique. The rich Arab families of Hadramaut, who had large estates on Java, brought the Maria Theresa

10 Edith Specht, "Eine lange und weite Reise. Die Geschichte des Maria - Theresien - Talers", in: Maria Theresia 1717 - 1780. Strategin - Mutter - Reformerin, catalogue of the exhibition held at the Art History Museum in Vienna, 2017, ed. Elfriede Iby, Martin Mutschlechner, Werner Telesko and Karl Vocelka (Vienna: Art History Museum, 2017), 78.

11 MARIA THERESIA DEI GRATIA ROMANORUM IMPERATRIX HUNGARIAE BOHEMIAEQUE REGINA / Maria Theresa by the grace of God Empress of the Romans, Queen of Hungary and Bohemia.

12 ARCHID. AVST. DUX. BURG. CO. TYR. (ARCHIDUX AVSTRIAE DUX BURGUNDIAE COMES TYROLIS / Archduke of Austria, Duke of Burgundy, Count of Tyrol).

13 The Conventionstaler was divided into 120 kreuzers. 
thaler with them to that part of the world. ${ }^{14}$ Soon the Maria Theresa thaler became so popular (mainly because of the high-quality silver content and the portrait of the buxom Monarch, which seemed appealing to the eye of the local populace) ${ }^{15}$ that the governments of other trading nations tailored or intended to tailor their trade coins according to it. In 1768, Doge Alvise Mocenigo (1763-78) invited the German engraver Anton Schabel to Venice to make the tallero di San Marco as similar as possible to the thaler of Maria Theresa. Henceforth, the Venetian thaler had a woman's bust on the obverse (an allegory of the Serenissima) with a pearl diadem resembling the one on the head of the empress depicted on the Maria Theresa thaler. In Prussia, Frederick the Great (1740-86) minted Levant trade thalers with his image on the obverse and the Prussian eagle on the reverse, but those thalers never took root in the Orient. For some time the French court entertained the thought of making their own Levant thaler. As the Austrian ambassador to France, Florimund Mercy Count d'Argenteau, describes in his dispatch from May 19, 1787, a certain amount of those thalers would be minted every year. They would have had a bust of Marie Antoinette (daughter of Maria Theresa) on the obverse, depicted in the similar fashion as her mother, with an inscription: MARIA ANTONIA CONJUX REGINA LUDOVICI XVI FRANCORUM IMPERATORIS. ${ }^{16}$ On the reverse, there would have been the coats of arms of Austria and France with an inscription: SIGNUM COMERCII FOEDERISQUE FRANCORUM IN ORIENTE. ${ }^{17}$ As in the case of the Maria Theresa thaler, there would have also been an inscription on the rim of the coin: UBIQUE MERCATORES AMICI. ${ }^{18}$ But that endeavour never came to fruition. The trading Republic of Ragusa imitated the Maria Theresa thaler with its Libertina, ${ }^{19}$ which had a female bust with a diadem on the obverse and the coat of arms of Ragusa on the reverse. The Maria Theresa thaler continued to be minted after the death of Maria Theresa because of the high demand for those coins, especially from merchants. All of the following coins bore the year 1780 and the marks of the mint masters (S.F.). Although demonetized on November 1, 1858, when the Austrian Empire introduced a new standard (through an imperial patent on September 19, 1857,

\footnotetext{
14 Franz Leypold, "Das Verbreitungsgebiet des Maria-Theresien-Talers", Numismatische Zeitschrift 94 (1980): 63.

15 When travelling down the Atbarah river (present day Sudan) in the 1860s, Sir Samuel White Baker noted: "The Austrian dollar of Maria Theresa is the only large coin current in his country; the effigy of the empress, with a very low dress and a profusion of bust, is, I believe, the charm that suits the Arab taste." S. W. Baker, Nile Tributaries of Abyssinia and the Sword Hunters of the Hamran Arabs (London: Macmillan and Co., 1867), 175-176.

16 Queen Marie Antoinette, wife of the French king Louis XVI.

17 Sign of the French trade and French alliance in the East.

18 Merchants are friends everywhere.

19 The silver coin of Ragusa issued between 1791 and 1795. Named after the inscription LIBERTAS (freedom) on the reverse. Frey, A Dictionary of Numismatic Names, 135.
} 
R.-G.-Bl. Nr. 169), the Maria Theresa thaler remained the official trade coin. ${ }^{20}$ Large numbers of Maria Theresa's thalers were used in the colonial wars. When leading the British punitive expedition to Abyssinia against Emperor Tewodros II (1855-68) in 1867-68, Lieutenant General Charles Napier took with him 5 million Maria Theresa thalers to pay for the local expenses. Further, Major General Charles George Gordon (Gordon Pasha) took half a million thalers with him to Khartoum. Italy acquired 12 million Maria Theresa thalers for the first Italo-Ethiopian War. At the end of the $19^{\text {th }}$ century, with the consolidation of the great European colonial empires, the colonial powers implemented a stricter monetary policy. The Maria Theresa thaler was supplanted by the French franc in northern and central Africa and by the Anglo-Indian rupee on the East coast of Africa, but it persisted in some areas, such as the Arabian Peninsula and Ethiopia.

The Maria Theresa thaler was legal tender in Saudi Arabia, Kuwait, the Emirates, the Sultanate of Muscat and Oman (until 1959), Yemen (until 1924-60), and Aden (until 1961). In these regions, it was known as abu-nuqta, the father of pearl or one with the pearl, which refers to the pearls on the diadem and the brooch on the obverse of the coin, and as abu-kush, the father of bird or one with the bird, which refers to the imperial eagle on the reverse.

Ethiopia has a special place in the history of Maria Theresa's thaler. According to Joseph Kalmer and Ludwig Hyun in their book Abessinien: Afrikas Unruhe-Herd (1935), over 20\% of all Maria Theresa thalers minted until 1931 ended up in Ethiopia. Austrian thalers became dominant in Ethiopia in the mid-18 ${ }^{\text {th }}$ century. James Bruce, Scottish traveller and writer, noticed that Austrian thalers, not as debased as other currencies, dominated the areas he visited during his 1768-73 expedition to discover the source of Nile. In 1894, Emperor Menelik II (1889-1913) began minting Menelik thalers with his effigy, styled after the Maria Theresa thaler, although with little success. In 1890, the Italians introduced the Eritrean tallero in their newly acquired colony of Eritrea. It had a crowned bust of Umberto I (1878-1900) on the obverse and an eagle with the coat of arms of the House of Savoy on the reverse. The Italians were hoping to impose it on the commerce with Ethiopia, but to no avail, so it was abandoned in 1921. Maria Theresa's thaler remained legal tender in Ethiopia till 1945 and Ethiopia even issued thaler banknotes. In Africa, Maria Theresa's thaler was known as: abu-teir (the father of bird), abu-gnuchtu (the father of content), reali moesi (the black thaler),

20 The Austrian Empire had reserved the right to mint the Maria Theresa thalers as trade coins even after the introduction of the Vereinstaler, as stated in Article 4 of the contract signed on January 24, 1857 by all the member states of the Zollverein: "Ein jeder der vertragenden Staaten wird Ausmünzungen auf solche Stücke beschränken, welche der dem vereinbarten Münzfusse (Artikel 2 und 3) entsprechenden Rechnungsweise gemäss sind. Ausnahmsweise bleibt es Oesterreich vorbehalten, noch ferner sogenannte 'Levantiner-Thaler' mit dem Bildnisse der Kaiserin Maria Theresia und mit der Jahreszahl 1780 im damaligen Schrot und Korn als Handelsmünze auszuprägen.” Carl Peez, Josef Raudnitz, Geschichte des Maria-Teresien-Thalers (Vienna: Carl Graeser, 1898), 76-77. 
ber, gersh, buter (the bird thaler), fransi, rial kebir (the great thaler), rial namsawi (the Austrian thaler), and qirsh.

Maria Theresa's thalers with the minting marks S.F. were originally minted in the Mint of Günzburg in the Margraviate of Burgau, Southern Germany. When the Habsburgs lost Burgau during the Napoleonic wars in 1805, the coining dies were moved to Vienna. From 1824 these were used in the Mints of Milan and Venice as well as in the Viennese central mint. After Austria lost Milan in 1859 and Venice in 1866, the Maria Theresa thaler was minted only in Vienna, where around 129 million coins were struck between 1858 and 1915. In an agreement with Chancellor Schuschnigg signed on 9 July 1935, Mussolini gained a 25-year concession over the production of the Maria Theresa thaler. It was part of the price Austria had to pay for Mussolini's frail protection; henceforth it could only mint 10000 pieces a year and was forbidden to take outside contracts. The Maria Theresa thaler was now being minted in Rome, in Zecca di Roma, up to 100000 pieces a day. Around 18 million thalers were shipped to East Africa to fuel $\mathrm{Mu}-$ ssolini's war against Ethiopia and the occupation of that country. Delegating the right to mint Maria Theresa thalers to Italy also meant that the prior exclusivity of minting those thalers at just one mint would no longer be internationally recognized. From 1937, ${ }^{21}$ Maria Theresa thalers were also minted at the Royal Mint in London and Birmingham for the British troops stationed in Sudan, Aden, and the Arab Territories around the Red Sea. During World War II, 19 million Maria Theresa thalers were minted in Bombay and Calcutta for the Indian troops deployed against the Italians in Africa. Following World War II, the United Kingdom continued minting Maria Theresa thalers for its crown colony of Aden and the surrounding areas. France, the Netherlands, and Belgium followed the British example and started minting the Maria Theresa thaler in Paris, Utrecht, and Brussels to support their economic interests in the Red Sea, the Persian Gulf, and the East Coast of Africa. It is estimated that between 1935 and 1949, 72 million Maria Theresa thalers were struck. In 1960, the 25-year Italian concession on minting the Maria Theresa thaler ended and the coining dies were returned to Vienna. Subsequently, Austria made diplomatic efforts to have the relevant governments cease minting the Maria Theresa thaler. The United Kingdom was the last country to formally agree to the Austrian request in February 1962. The Maria Theresa thaler bearing the date of 1780 is now a "protected coin"22 under

\footnotetext{
${ }^{21}$ Jeffrey E. Stokes, "Die Nachprägungen des Maria-Theresien-Talers in englischem Auftrag aus Wien, London, Brüssel, Bombay und Birmingham”, Numismatische Zeitschrift 94 (1980): 69.

22 "Protected coins" means that under the British Forgery and Counterfeiting Act of 1981 certain coins are protected and counterfeiting them is just as serious an offence as counterfeiting coins of the United Kingdom. "Forgery and Counterfeiting Act 1981", Parliament of the United Kingdom, https://www.legislation.gov.uk/ukpga/1981/45 (last accessed on October 20, 2017). "The Forgery and Counterfeiting (Protected Coins) Order 1981”, Parliament of the United Kingdom, http://www. legislation.gov.uk/uksi/1981/1505/contents/made (last accessed on October 20, 2017).
} 
the British Forgery and Counterfeiting Act of 1981, Part II, section 27 (1). The Maria Theresa thaler continues to be produced by the Austrian Mint according to the Austrian law, ${ }^{23}$ and is available in both proof and uncirculated conditions.

With over 400 million struck, the Maria Theresa thaler from 1780 remains one of the most popular modern-era coins. Its beauty and quality still speak of the grandeur of the imperial times now long past. It is Maria Theresa's exegi monumentum - a fitting memento of the reign of the great queen and empress, reformer, and Landesmutter.

${ }_{23}$ Scheidemünzen-Gesetz 1988, \$15 (I). “Gesamte Rechtsvorschrift für Scheidemünzengesetz 1988," Bundeskanzleramt (AT), https://www.ris.bka.gv.at/GeltendeFassung.wxe?Abfrage=Bundesnormen\&Gesetzesnummer $=10004576$ (last accessed on October 20, 2017). 


\section{Published sources and literature}

“Gesamte Rechtsvorschrift für Scheidemünzengesetz 1988”, Bundeskanzleramt (AT) https://www.ris.bka.gv.at/GeltendeFassung.wxe?Abfrage=Bundesnormen\& Gesetzesnummer $=10004576$ (last accessed on October 20, 2017).

"Forgery and Counterfeiting Act 1981", Parliament of the United Kingdom https:// www.legislation.gov.uk/ukpga/1981/45 (last accessed on October 20, 2017).

"The Forgery and Counterfeiting (Protected Coins) Order 1981", Parliament of the United Kingdom, http://www.legislation.gov.uk/uksi/1981/1505/contents/ made (last accessed on October 20, 2017).

Baker, Samuel W. Nile Tributaries of Abyssinia and the Sword Hunters of the Hamran Arabs. London: Macmillan and Co., 1867.

Frey, Albert R. A Dictionary of Numismatic Names their Official and Popular Designations. New York: The American Numismatic Society, 1917.

Leypold, Franz. "Das Verbreitungsgebiet des Maria-Theresien-Talers". Numismatische Zeitschrift 94 (1980): 63-64.

Logie, Christiane. "The Thaler. European Coinage of Modern Times". In: One Money for Europe, catalogue of the exhibition held at the $11^{\text {th }}$ International Congress of Numismatics, September 8-13, 1991, ed. Monique Sibille and Lieve Viaene-Awouters, 121-125. Brussels: Belgian Municipal Credit Institution, 1991.

Peez Carl; Raudnitz Josef. Geschichte des Maria-Teresien-Thalers. Wien: Carl Graeser, 1898.

Pliny the Elder. Natural History IV / Libri XII - XVI. Trans. by Harris Rackham. Cambridge, Massachusetts: Harvard University Press, 1960.

Schmid, Peter. "Sigmund (Siegmund, Sigismund[us]) 'der Münzreiche”. In: Neue Deutsche Biographie (on-line), vol. 24. München: Historische Kommission bei der Bayerischen Akademie der Wissenschaften, 2010.

Specht, Edith. "Eine lange und weite Reise. Die Geschichte des Maria - Theresien - Talers". In: Maria Theresia 1717 - 1780. Strategin - Mutter - Reformerin, catalogue of the exhibition held at the Art History Museum in Vienna, 2017, ed. Elfriede Iby, Martin Mutschlechner, Werner Telesko and Karl Vocelka, 78-82. (Vienna: Art History Museum, 2017.

Stokes, Jeffrey E. “Die Nachprägungen des Maria-Theresien-Talers in englischem Auftrag aus Wien, London, Brüssel, Bombay und Birmingham". Numismatische Zeitschrift 94 (1980): 65-73.

Suhle, Arthur. “Graumann, Johann Philipp”. In: Neue Deutsche Biographie (on-line), vol. 7. München: Historische Kommission bei der Bayerischen Akademie der Wissenschaften, 1966. 


\section{Kristian Gotić}

\section{The thaler of Maria Theresa from 1780: Der Levantetaler}

\section{Sažetak}

Talir Marije Terezije iz 1780. jedan je od najpoznatijih srebrnjaka na svijetu. Radi se o taliru - vrsti srebrnoga kovanoga novca, promjera oko $40 \mathrm{~mm}$ i težine oko $30 \mathrm{~g}$, koji se koristio u Europi od 16. do druge polovice 19. stoljeća. Talir Marije Terezije iz 1780., zbog svoje kakvoće i estetskoga izgleda bio je omiljeno platežno sredstvo na Levantu, Arapskom poluotoku i Istočnoj Africi. Osim što je bio trgovačka kovanica, talir Marije Terezije je u Etiopiji (do 1945.) i zemljama Arapskog poluotoka zbog svoje popularnosti bio i legalno platežno sredstvo (Saudijska Arabija, Kuvajt, Emirati, Sultanat Muscat i Oman do 1959., Jemen (1924. - 1960.), britanska krunska kolonija Aden (do 1961.).

Ključne riječi: srebrnjak, talir, talir Marije Terezije iz 1780., Levant, Arapski poluotok, Etiopija 